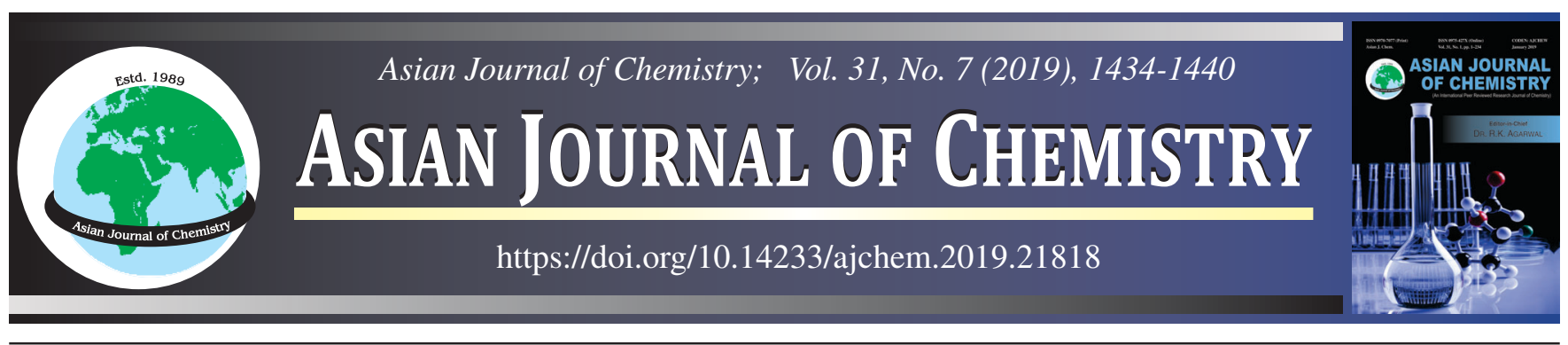

\title{
Synthesis, Characterization and Biological Studies on Cobalt(II) and Nickel(II) Complexes with Mannich Base 2-(Pyrrolidin-1-ylmethyl)isoindoline-1,3-dione
}

\author{
M. Yosuva Suvaikin ${ }^{1, *}$ and C. Kalaivanan ${ }^{2}$
}

${ }^{1}$ Department of Chemistry, H.H. The Rajah's College (Autonomous), Pudukkottai-622001, India

${ }^{2}$ Department of Chemistry, K. Ramakrishnan College of Technology, Tiruchirappalli-621112, India

*Corresponding author: E-mail: kalaikannan.durai@gmail.com; yosu77s@gmail.com

Received: 15 November 2018;

Accepted: 16 December 2018;

Published online: 21 May 2019;

AJC-19391

\begin{abstract}
| A new Mannich base 2-(pyrrolidin-1-ylmethyl)isoindoline-1,3-dione was synthesized by the condensation of phthalimide, formaldehyde and pyrrolidine and was characterized on the basis of elemental analysis and IR, UV-visible, ${ }^{1} \mathrm{H}$ and ${ }^{13} \mathrm{C} \mathrm{NMR}$ data. Cobalt(II) and nickel(II) complexes of new Mannich base were synthesized and characterized by elemental analysis, electrical conductance, electronic and IR spectra, magnetic measurements, thermal analysis and cyclic voltammetric studies. From IR data, it is inferred that the ligand is neutral bidentate bonding through pyrrolidine ring containing nitrogen and one of the two carbonyl oxygens. The magnetic moment | values and electronic spectral data show that all the complexes studied are tetrahedral except Co(II) chloro complex. The electrochemical studies show that $\mathrm{Co}(\mathrm{II}) / \mathrm{Co}(\mathrm{I})$ redox couple exists during electrolysis. Thermal results indicate that $\mathrm{Co}$ (II) sulphato and $\mathrm{Ni}$ (II) chloro complexes undergo two stage decompositions to produce $\mathrm{CoSO}_{4}$ and $\mathrm{NiO}$, respectively as final residues and that the ligand forms a polymer of formaldehyde as an intermediate. The antimicrobial activity measured by the agar well diffusion method showed that the metal complexes are more active than the ligand probably because of the chelation effect.
\end{abstract}

Keywords: Isoindoline-1,3-dione, Mannich base, Cyclic voltammetry, Thermal decomposition, Antimicrobial activity.

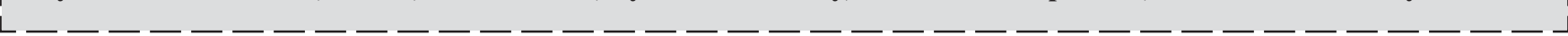

\section{INTRODUCTION}

Cyclic imides such as phthalimides, succinimides, etc. have received attention due to their antibacterial, antifungal, analgesic [1], anxiolytic [2] and antitumor activities [3,4] and HIV-1 reverse transcriptase inhibitor property [5]. Their molecules contain an imide ring and a general structural feature -CO-N(R)-CO- and they are liphophilic/hydrophobic and neutral. They can easily diffuse through the biological cell membrane causing potential biological activities and hence can serve as pharmacophores. In particular, phthalimides are reported as herbicides, insecticides, antipsychotics and anti-inflammatory agents [6-9]. Further, when imide is transformed into a Mannich base, it can enhance its biological behaviour and coordination tendency [10]. The new Mannich base which is presently studied is having a pyrrolidine moiety in addition to phthalimide moiety. The pyrrolidine skeleton occurs in many families of biologically important compounds. Pyrrolidine derivatives are found to have antimicrobial activity against various pathogens except
Basillus subtilis [11]. They also possess anti-influenza virus [12], anticonvulsant [13,14] and other antiviral [15] activities.

There have been recent reports on the synthesis and biological properties of Mannich bases derived from imides including that of phthalimide and the isolation and characterization of transition metal complexes of those Mannich bases. Abdullahi amd Rajeswari [16] have synthesized and characterized a novel Mannich base by the direct condensation of succinimide, benzaldehyde and thiourea. Tamilvendan et al. [17] have reported another Mannich base by condensing succinimide, benzaldehyde and morpholine. Novel Mannich bases like 1-[(phenylamino)methyl]pyrrolidine-1,3-dione and 2[(phenylamino)methyl]isoindoline-1,3-dione have been synthesized and their complexes with $\mathrm{Co}$ (II), $\mathrm{Ni}(\mathrm{II}), \mathrm{Cu}$ (II) and $\mathrm{Zn}$ (II) ions have also been studied. Recently, we have reported synthesis and antimicrobial activity of 2-(dimethylaminomethyl)isoindoline-1,3-dione and 2-(diethylaminomethyl)isoindoline-1,3-dione and their $\mathrm{Co}(\mathrm{II})$ and $\mathrm{Ni}$ (II) complexes. Ramesh [18] also reported $\mathrm{Co}$ (II), $\mathrm{Ni}$ (II) and $\mathrm{Cu}$ (II) complexes of $\mathrm{N}$-(morpholinomethyl)-

This is an open access journal, and articles are distributed under the terms of the Creative Commons Attribution-NonCommercial-ShareAlike 4.0 (CC BY-NC-SA 4.0) International License which allows readers to freely read, download, copy, distribute, print, search, or link to the full texts of its articles and to use them for any other lawful non-commercial purpose as long as the original source is duly acknowledged. 
succinimide. In continuation, we report herein the synthesis, characterization and antimicrobial screening of $\mathrm{Co}$ (II) and $\mathrm{Ni}$ (II) complexes of 2-(pyrrolidin-1-ylmethyl)isoindoline-1,3-dione.

\section{EXPERIMENTAL}

Elemental analyses of the synthesized compounds were performed using Carlo Erba 1108, Thomas $\mathrm{CH}$ analyzer and Coleman N analyzer. Metal, chloride and sulphate contents of the complexes were estimated according to the standard procedures [19]. The molar conductances of metal complexes were measured in $\sim 10^{-3} \mathrm{M} \mathrm{DMF}$ solutions at room temperature using Systronics direct reading Conductivity Meter 304 . The magnetic susceptibility measurements were done to find out the effective magnetic moments of metal ions by using a Gouy magnetic balance at room temperature, where $\mathrm{Hg}\left[\mathrm{Co}(\mathrm{SCN})_{4}\right]$ was used as the calibrant and diamagnetic corrections were applied using Pascal's constants [20]. Infrared spectral measurements were made for the free ligand and its metal complexes as $\mathrm{KBr}$ pellets using Perkin Elmer Spectrum-1 FT-IR spectrometer in the region of 4000-400 $\mathrm{cm}^{-1}$. Far IR spectra were recorded on a Bruker IFS-66V FT-IR spectrometer in polythene support. The ${ }^{1} \mathrm{H}$ - and ${ }^{13} \mathrm{C}-\mathrm{NMR}$ spectra of the ligand were recorded on JEOL GSX-400FT. NMR spectrometer employing TMS as internal reference and DMSO- $d_{6}$ as solvent at ambient temperature. The UV-visible spectra of the compounds in DMF solutions were measured using Perkin Elmer EZ 301 spectrometer in the working range of 1100-190 nm. Electrochemical behaviour of $\mathrm{CoCl}_{2} \cdot \mathrm{L} \cdot \mathrm{H}_{2} \mathrm{O}$ as a representative case was investigated with an electrochemical analyzer CHI-620A, USA-Version 4.01 in HPLC grade DMF containing $\mathrm{NaClO}_{4}$ as supporting electrolyte. The three electrode assembly consisted of glassy carbon working electrode, $\mathrm{Ag} / \mathrm{AgCl}(3 \mathrm{M} \mathrm{KCl})$ reference electrode and Pt wire auxiliary electrode. All measurements were carried out at room temperature after purging the solutions with nitrogen gas [21]. Thermal analyses of the ligand and metal complexes were performed by recording simultaneous TG/DTA patterns on a Perkin Elmer Diamond TG/DTA thermal analyzer in an atmosphere of air at a linear heating rate of $10^{\circ} \mathrm{C}$ from ambient to $900{ }^{\circ} \mathrm{C}$.

Synthesis of 2-(pyrrolidin-1-ylmethyl)isoindoline-1,3dione: A new Mannich base 2-(pyrrolidin-1-ylmethyl)isoindoline-1,3-dione was synthesized by the Mannich condensation of phthalimide, formaldehyde and pyrrolidine. Phthalimide $(4.71 \mathrm{~g}, 0.1 \mathrm{~mol})$ was mixed with $37 \%$ aqueous formaldehyde $(7.5 \mathrm{~mL}, 0.1 \mathrm{~mol})$ and pyrrolidine $(12.21 \mathrm{~mL}, 0.1 \mathrm{~mol})$ with constant stirring at room temperature and the clear solution obtained was kept aside for $2 \mathrm{~h}$. The colourless crystalline product formed was filtered, washed with distilled water several time and finally washed with a small amount of acetone. It was dried at $70^{\circ} \mathrm{C}$ in an air oven and stored in a vacuum desiccator (yield: $93 \%$ ). The colourless compound was recrystallized from ethanol (m.p. $122^{\circ} \mathrm{C}$ ).

Preparation of metal complexes: A hot ethanolic solution (20 mL) of metal(II) salt was added dropwise to hot ethanolic solution $(20 \mathrm{~mL})$ of Mannich base ligand in 2:1 or 1:1 mol ratio with constant stirring and the mixture was digested in a water bath for an hour. The solid metal complexes were filtered, washed with hot ethanol and dried at $80{ }^{\circ} \mathrm{C}$ in a hot air oven and finally preserved in a vacuum desiccator.

in vitro Antimicrobial activity: The antibacterial screening of Mannich base and its metal complexes against E. coli and $S$. aureus was done using nutrient agar medium and antifungal assay against $C$. albicans and $A$. niger was carried out using Rose Bengal chloromphenicol agar medium. In both cases, agar well diffusion technique was employed and sample solutions (in DMF) of $25,50,75$ and $100 \mu \mathrm{g} / \mathrm{mL}$ concentrations were filled into the wells. Kanamycin and tetracyclin were used as standard drugs in the antibacterial assay and amphotericin and nystatin were the standard drugs in antifungal assay.

\section{RESULTS AND DISCUSSION}

Structural characterization of Mannich base: The synthesized compound is non-hygroscopic and insoluble in water, chloroform, carbon tetrachloride, ether, benzene and $n$-hexane, but soluble in methanol, ethanol, 2-propanol, 1butanol, DMSO and DMF. The results of elemental analysis (Table-1) and the molecular mass determined by Rast method at 229.38 indicate that the molecular formula of synthesized Mannich base is $\mathrm{C}_{13} \mathrm{H}_{14} \mathrm{~N}_{2} \mathrm{O}_{2}$. The electronic spectrum of Mannich base in DMF solution registers intense bands at $273 \mathrm{~nm}$ due to $\mathrm{n}-\pi^{*}$ transition of the carbonyl group and at $235 \mathrm{~nm}$ due to $\pi-\pi^{*}$ transitions of both carbonyl group and aromatic ring [22].

The characteristic IR absorption bands of synthesized Mannich base are listed in Table-2. The bands are slightly shifted from those of pyrrolidine and phthalimide because of formation of the new compound by Mannich condensation. The absorption bands observed at 1765 (sh) and $1712 \mathrm{~cm}^{-1}$ are assigned to $\mathrm{vCO}$ of phthalimide moiety and the bands located at 1185 and $1150 \mathrm{~cm}^{-1}$ are due to $\mathrm{VCNC}$ of pyrrolidine moiety. The bands found in the region 1596-1430 $\mathrm{cm}^{-1}$ are attributed to the aromatic $\mathrm{C}=\mathrm{C}$ stretching vibrations while the absorptions observed at 745 and $713 \mathrm{~cm}^{-1}$ are due to the ortho-substitution of benzene ring in the phthalimide moiety $[22,23]$.

The ${ }^{1} \mathrm{H}$ NMR spectrum of synthesized Mannich base showed four signals indicating four different types of protons.

TABLE-1

ANALYTICAL AND CONDUCTANCE DATA FOR Co(II) AND Ni(II) COMPLEXES OF LIGAND

\begin{tabular}{|c|c|c|c|c|c|c|c|}
\hline \multirow{2}{*}{ Compound } & \multirow{2}{*}{ m.f. } & \multicolumn{5}{|c|}{ Elemental analysis (\%): Found (calcd.) } & \multirow{2}{*}{$\begin{array}{c}\Lambda_{\mathrm{M}} \\
\left(\Omega^{-1} \mathrm{~cm}^{2} \mathrm{~mol}^{-1}\right)\end{array}$} \\
\hline & & $\mathrm{C}$ & $\mathrm{H}$ & $\mathrm{N}$ & Metal & Anion & \\
\hline $\mathrm{L}$ & $\mathrm{C}_{13} \mathrm{H}_{14} \mathrm{~N}_{2} \mathrm{O}_{2}$ & $67.94(67.82)$ & $6.16(6.08)$ & $12.11(12.17)$ & - & - & - \\
\hline $\mathrm{CoCl}_{2} \cdot \mathrm{L} \cdot 2 \mathrm{H}_{2} \mathrm{O}$ & $\mathrm{C}_{13} \mathrm{H}_{18} \mathrm{~N}_{2} \mathrm{O}_{4} \mathrm{CoCl}_{2}$ & $39.36(39.40)$ & $4.11(4.04)$ & $7.12(7.07)$ & $14.78(14.88)$ & $17.96(17.93)$ & 36 \\
\hline $2 \mathrm{Co}\left(\mathrm{NO}_{3}\right)_{2} \cdot \mathrm{L}$ & $\mathrm{C}_{13} \mathrm{H}_{14} \mathrm{~N}_{6} \mathrm{O}_{14} \mathrm{Co}_{2}$ & $26.12(26.17)$ & $2.39(2.34)$ & $14.15(14.09)$ & $19.73(19.77)$ & $-(41.61)$ & 23 \\
\hline $2 \mathrm{CoSO}_{4} \cdot \mathrm{L} \cdot \mathrm{H}_{2} \mathrm{O}$ & $\mathrm{C}_{13} \mathrm{H}_{16} \mathrm{~N}_{2} \mathrm{O}_{11} \mathrm{~S}_{2} \mathrm{Co}_{2}$ & $27.98(27.96)$ & $2.81(2.86)$ & $5.06(5.02)$ & $21.28(21.30)$ & $34.44(34.41)$ & 19 \\
\hline $2 \mathrm{NiCl}_{2} \cdot \mathrm{L} \cdot \mathrm{H}_{2} \mathrm{O}$ & $\mathrm{C}_{13} \mathrm{H}_{16} \mathrm{~N}_{2} \mathrm{O}_{3} \mathrm{NiCl}_{4}$ & $27.53(29.58)$ & $3.44(3.41)$ & $5.32(5.30)$ & $22.28(22.25)$ & $26.88(26.92)$ & 37 \\
\hline $\mathrm{Ni}\left(\mathrm{NO}_{3}\right)_{2} \cdot \mathrm{L}$ & $\mathrm{C}_{13} \mathrm{H}_{14} \mathrm{~N}_{4} \mathrm{O}_{8} \mathrm{Ni}$ & $37.91(37.79)$ & $3.46(3.39)$ & $13.52(13.56)$ & $14.24(14.22)$ & $-(30.04)$ & 33 \\
\hline $\mathrm{NiSO}_{4} \cdot \mathrm{L}$ & $\mathrm{C}_{13} \mathrm{H}_{14} \mathrm{~N}_{2} \mathrm{O}_{6} \mathrm{SNi}$ & $40.49(40.58)$ & $3.71(3.63)$ & $7.21(7.27)$ & $15.31(15.26)$ & $24.87(24.95)$ & 46 \\
\hline
\end{tabular}


TABLE-2

IR SPECTRAL DATA $\left(\mathrm{cm}^{-1}\right)$ OF MANNICH BASE L AND ITS Co(II) AND Ni(II) COMPLEXES

\begin{tabular}{|c|c|c|c|c|c|c|c|c|}
\hline Compound & $v(\mathrm{CO})$ & $v(\mathrm{CNC})$ & $v(\mathrm{MO})$ & $v(\mathrm{MN})$ & $v(\mathrm{MX})$ & $v(\mathrm{OH})$ & $\delta(\mathrm{HOH})$ & $\operatorname{\rho r}(\mathrm{HOH})$ \\
\hline $\begin{array}{l}\mathrm{L} \\
\left(\mathrm{C}_{13} \mathrm{H}_{14} \mathrm{~N}_{2} \mathrm{O}_{2}\right)\end{array}$ & 1765,1712 & 1185,1150 & - & - & - & - & - & - \\
\hline $\mathrm{CoCl}_{2} \cdot \mathrm{L} \cdot 2 \mathrm{H}_{2} \mathrm{O}$ & 1726,1604 & 1143,1052 & 532 & 430 & 360 & 3487 & 1604 & 842 \\
\hline $2 \mathrm{Co}\left(\mathrm{NO}_{3}\right)_{2} \cdot \mathrm{L}$ & 1718,1640 & 1139,1053 & 534 & 440 & - & - & - & - \\
\hline $2 \mathrm{CoSO}_{4} \cdot \mathrm{L} \cdot \mathrm{H}_{2} \mathrm{O}$ & 1735,1605 & 1146,1112 & 487 & 419 & - & 3483 & 1605 & 881 \\
\hline $2 \mathrm{NiCl}_{2} \cdot \mathrm{L} \cdot \mathrm{H}_{2} \mathrm{O}$ & 1727,1597 & $1177,1144,1051$ & 530 & 460 & 340 & 3485 & 1598 & 909 \\
\hline $\mathrm{Ni}\left(\mathrm{NO}_{3}\right)_{2} \cdot \mathrm{L}$ & 1717,1623 & 1141,1045 & 477 & 422 & - & - & - & - \\
\hline $\mathrm{NiSO}_{4} \cdot \mathrm{L}$ & 1713,1639 & 1128 & 534 & 440 & - & - & - & - \\
\hline
\end{tabular}

The singlet at $7.84 \mathrm{ppm}$ is assigned to aromatic protons. The chemical shift at $2.55-2.48 \mathrm{ppm}$ is due to $\mathrm{N}\left(\mathrm{CH}_{2}\right)_{2}$ protons and that at $1.6 \mathrm{ppm}$ is due to other $\mathrm{CH}_{2}$ protons of pyrrolidine moiety. The proton signal seen at $4.5 \mathrm{ppm}$ is attributed to the $\mathrm{N}-\mathrm{CH}_{2}-\mathrm{N}$ linkage. The intensity ratio obtained for the signals correlates with the number of protons under each chemically equivalent set.

The ${ }^{13} \mathrm{C}$ NMR spectrum of Mannich base shows low intensity signal at 168.73 ppm due to carbonyl carbons and at 134.47123.09 ppm due to aromatic carbons. The $\mathrm{N}\left(\mathrm{CH}_{2}\right)_{2}$ carbons of pyrrolidine moiety give a signal at $49.88 \mathrm{ppm}$ while other $\mathrm{CH}_{2}$ carbons resonated at $23.25 \mathrm{ppm}$. The chemical shift of methylene carbon linking the $\mathrm{N}$-atoms of pyrrolidine and phthalimide moieties is observed at $54.67 \mathrm{ppm}$.

The crystal structure of synthesized Mannich base was already reported [24] and hence mass spectral study was not attempted. Thus based on physical, chemical and crystallographic studies the molecular structure is confirmed as given in Fig. 1.

Further optical transmission studies have been carried out to evaluate the optical parameters $(\mathrm{K}, \alpha, \mathrm{R})$ and the optical band gap $\left(E_{g}\right)$ [25]. As a consequence of a wide band gap (5.16 eV), this Mannich base crystal has a large transmittance in the visible region making it suitable for non-linear optical (NLO) applications such as fabrication of various photonic devices.

Structural characterization of metal complexes: All the metal complexes isolated are coloured, stable in air and nonhygroscopic. They are insoluble in water and common organic solvents, but soluble in DMF and DMSO. The metal complexes have been analyzed for $\mathrm{C}, \mathrm{H}, \mathrm{N}$, metal and anion contents. Their analytical and electrical conductivity data are given in Table-1. The observed molar conductance data revealed that the metal complexes are non-electrolytes and the anions are bound to the metal ions [26].

Infrared spectra: The Mannich base ligand (L) has four coordination sites viz. two carbonyl $\mathrm{O}$, one imide $\mathrm{N}$ and one tertiary amino $\mathrm{N}$ atom. A comparison of IR spectra of metal (II) complexes with that of the ligand would suggest the actual coordination sites of the ligand and the modes of coordination of oxoanions. The structurally important IR absorption frequencies of $\mathrm{Co}$ (II) and $\mathrm{Ni}$ (II) complexes are presented in Table-2. The free ligand exhibits characteristic vibrational absorption bands at 1765 (sh) and $1712 \mathrm{~cm}^{-1}$, which are due to carbonyl stretching vibrations. In the spectra of metal complexes, the ligand band at $1712 \mathrm{~cm}^{-1}$ has undergone splitting into two bands

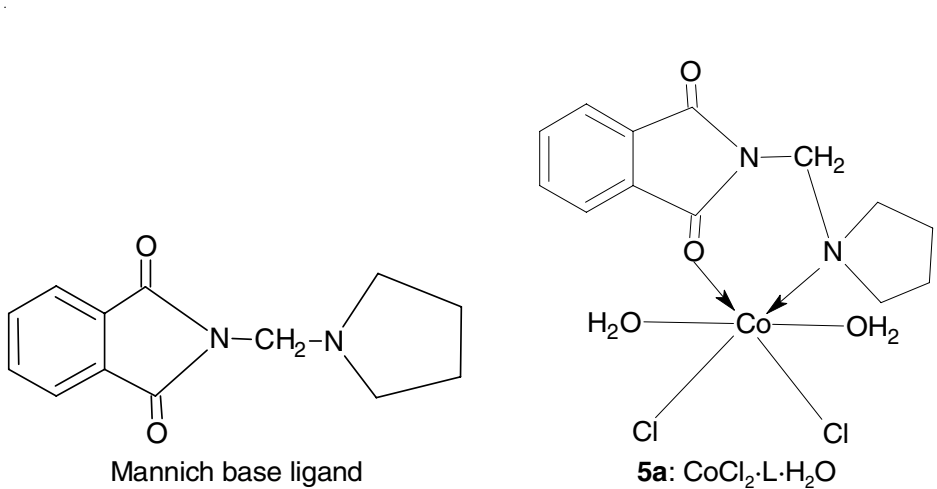

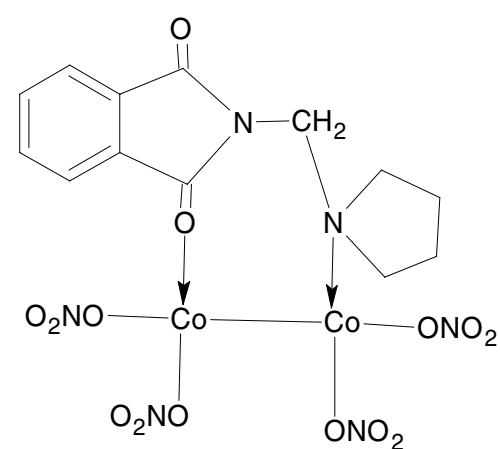

5b: $2 \mathrm{Co}\left(\mathrm{NO}_{3}\right)_{2} \cdot \mathrm{L}$<smiles>[X][M]OC(=O)c1ccccc1CN1C(=[X])c2ccccc2C1=O</smiles>

5c: $2 \mathrm{MX}_{2} \cdot \mathrm{L} \cdot \mathrm{H}_{2} \mathrm{O}$

$\left[\mathrm{M}=\mathrm{Co}(\mathrm{II}) ; \mathrm{X}=0.5 \mathrm{SO}_{4} ; \mathrm{M}=\mathrm{Ni}(\mathrm{II}) ; \mathrm{X}=\mathrm{Cl}\right]$

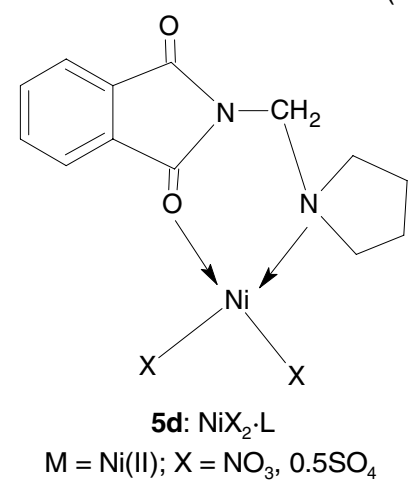

Fig. 1. Proposed structures of the $\mathrm{Co}(\mathrm{II})$ and $\mathrm{Ni}(\mathrm{II})$ complexes 
in each case one at a higher region $1720-1709 \mathrm{~cm}^{-1}$ and another at a lower region $1639-1600 \mathrm{~cm}^{-1}$, indicating the coordination of one of the two carbonyl oxygens to the metal ions [17,27,28]. Further, the $\mathrm{C}-\mathrm{N}-\mathrm{C}$ stretching vibrations of free ligand appeared at 1185 and $1150 \mathrm{~cm}^{-1}$. These vibrations have lowered to $1146-$ 1109 and $1128-1045 \mathrm{~cm}^{-1}$ regions in the spectra of metal (II) complexes indicating the bonding of pyrrolidine ring $\mathrm{N}$ to the metal centre [17,29].

The coordination of carbonyl oxygen and tertiary amino nitrogen atoms to the metal centre is also evidenced by the occurrence of $v(\mathrm{M}-\mathrm{O})$ and $v(\mathrm{M}-\mathrm{N})$ at $534-477$ and $460-419 \mathrm{~cm}^{-1}$, respectively. The binding of anions to the metal centre is also inferred from existence of vibrational bands in the IR spectra of nitrato and sulphato complexes. The $\mathrm{Co}$ (II) and $\mathrm{Ni}$ (II) nitrato complexes exhibit $v_{5}, v_{1}$ and $v_{2}$ bands at 1459-1458, 13901388 and $1052-1045 \mathrm{~cm}^{-1}$, respectively due to unidentate coordination of the nitrato groups, as the separation between $v_{5}$ and $v_{1}$ is very small [30]. The bidentate coordination of sulphato groups in $\mathrm{Co}(\mathrm{II})$ and $\mathrm{Ni}(\mathrm{II})$ complexes is revealed by the $\mathrm{v}_{3}$, $v_{1}, v_{4}$ and $v_{2}$ bands appearing at 1189-1112, 881-850, 612611 and 534-487 $\mathrm{cm}^{-1}$ [30]. The IR spectra of complexes such as $\mathrm{CoCl}_{2} \cdot \mathrm{L} \cdot 2 \mathrm{H}_{2} \mathrm{O}, 2 \mathrm{CoSO}_{4} \cdot \mathrm{L} \cdot \mathrm{H}_{2} \mathrm{O}$ and $2 \mathrm{NiCl}_{2} \cdot \mathrm{L} \cdot \mathrm{H}_{2} \mathrm{O}$ exhibit absorption bands due to coordinated water at 3487-3483 ( $\mathrm{vOH})$, $1605-1598(\delta \mathrm{HOH}), 909-842(\mathrm{\rho rHOH}), 645-612(\rho w \mathrm{HOH})$ and $540-461 \mathrm{~cm}^{-1}(\mathrm{vM}-\mathrm{O})$. The thermal decomposition studies on $2 \mathrm{CoSO}_{4} \cdot \mathrm{L} \cdot \mathrm{H}_{2} \mathrm{O}$ as a representative case also indicate the presence of coordinated water molecule. The far IR absorption bands observed at $360-340 \mathrm{~cm}^{-1}$ are due to $\mathrm{M}-\mathrm{Cl}$ vibrations in the chloro complexes.

Electronic spectral and magnetic studies: The electronic spectral band of ligand origin observed at $273 \mathrm{~nm}$ due to $n-\pi^{*}$ transition of carbonyl groups is blue shifted in all the metal complexes indicating the coordination of a carbonyl oxygen to the metal centre. The colours, magnetic moments, absorption maxima and the transition assignments of metal complexes are shown in Table- 3 and the ligand field parameters are given in Table-4. The pink coloured Co(II) chloro complex exhibited electronic transition bands at 6822,14814 and $18963 \mathrm{~cm}^{-1}$ due to ${ }^{4} \mathrm{~T}_{1 \mathrm{~g}}(\mathrm{~F}) \rightarrow{ }^{4} \mathrm{~T}_{2 \mathrm{~g}}(\mathrm{~F})\left(\mathrm{V}_{1}\right) ;{ }^{4} \mathrm{~T}_{1 \mathrm{~g}}(\mathrm{~F}) \rightarrow{ }^{4} \mathrm{~A}_{2 \mathrm{~g}}(\mathrm{~F})\left(\mathrm{V}_{2}\right)$ and ${ }^{4} \mathrm{~T}_{1 \mathrm{~g}}(\mathrm{~F}) \rightarrow$ ${ }^{4} \mathrm{~T}_{\mathrm{lg}}(\mathrm{P})\left(\mathrm{V}_{3}\right)$ transitions and at $28292 \mathrm{~cm}^{-1}$ is due to charge transfer transition. The $v_{2} / v_{1}$ ratio for $\mathrm{Co}$ (II) chloro complex is 2.17 , which falls in the range 2.00-2.82 indicated a high

TABLE-3

ELECTRONIC SPECTRAL AND MAGNETIC DATA OF Co(II) AND Ni(II) COMPLEXES OF LIGAND

\begin{tabular}{|c|c|c|c|c|c|}
\hline Complex & Colour & $\mu_{\text {eff }}($ B.M) & $\begin{array}{l}\text { Coordination } \\
\text { environment }\end{array}$ & $\begin{array}{l}\text { Absorption maxima } \\
\left(\mathrm{cm}^{-1}\right)\end{array}$ & $\begin{array}{c}\text { Transition } \\
\text { assignments }\end{array}$ \\
\hline $\mathrm{CoCl}_{2} \cdot \mathrm{L} \cdot 2 \mathrm{H}_{2} \mathrm{O}$ & Pinkish red & 5.16 & {$\left[\mathrm{CoO}_{3} \mathrm{NCl}_{2}\right]$} & $\begin{array}{c}6822 \\
14814 \\
18963 \\
28262\end{array}$ & $\begin{array}{c}\left.{ }^{4} \mathrm{~T}_{1 \mathrm{~g}} \mathrm{~F}\right) \rightarrow{ }^{4} \mathrm{~T}_{2 \mathrm{~g}}(\mathrm{~F}) \\
{ }^{4} \mathrm{~T}_{1 \mathrm{~g}}(\mathrm{~F}) \rightarrow{ }^{4} \mathrm{~A}_{2 \mathrm{~g}}(\mathrm{~F}) \\
{ }^{4} \mathrm{~T}_{1 \mathrm{~g}}(\mathrm{~F}) \rightarrow{ }^{4} \mathrm{~T}_{1 \mathrm{~g}}(\mathrm{P}) \\
\mathrm{CT}\end{array}$ \\
\hline $2 \mathrm{Co}\left(\mathrm{NO}_{3}\right)_{2} \cdot \mathrm{L}$ & Blue & 1.09 & $\begin{array}{c}{\left[\mathrm{CoO}_{2} \mathrm{NCo}\right]} \\
{\left[\mathrm{CoO}_{3} \mathrm{Co}\right]}\end{array}$ & $\begin{array}{c}3912 \\
6726 \\
14426 \\
26168 \\
\end{array}$ & $\begin{array}{c}{ }^{4} \mathrm{~A}_{2}(\mathrm{~F}) \rightarrow{ }^{4} \mathrm{~T}_{2}(\mathrm{~F}) \\
{ }^{4} \mathrm{~A}_{2}(\mathrm{~F}) \rightarrow{ }^{4} \mathrm{~T}_{1}(\mathrm{~F}) \\
{ }^{4} \mathrm{~A}_{2}(\mathrm{~F}) \rightarrow{ }^{4} \mathrm{~T}_{1}(\mathrm{P}) \\
\mathrm{CT}\end{array}$ \\
\hline $2 \mathrm{CoSO}_{4} \cdot \mathrm{L} \cdot \mathrm{H}_{2} \mathrm{O}$ & Greyish blue & 4.21 & {$\left[\mathrm{CoO}_{4}\right]\left[\mathrm{CoO}_{3} \mathrm{~N}\right]$} & $\begin{array}{c}3869 \\
6938 \\
14693 \\
26326 \\
\end{array}$ & $\begin{array}{c}{ }^{4} \mathrm{~A}_{2}(\mathrm{~F}) \rightarrow{ }^{4} \mathrm{~T}_{2}(\mathrm{~F}) \\
{ }^{4} \mathrm{~A}_{2}(\mathrm{~F}) \rightarrow{ }^{4} \mathrm{~T}_{1}(\mathrm{~F}) \\
{ }^{4} \mathrm{~A}_{2}(\mathrm{~F}) \rightarrow{ }^{4} \mathrm{~T}_{1}(\mathrm{P}) \\
\mathrm{CT}\end{array}$ \\
\hline $2 \mathrm{NiCl}_{2} \cdot \mathrm{L} \cdot \mathrm{H}_{2} \mathrm{O}$ & Parrot green & 4.17 & $\begin{array}{c}{\left[\mathrm{NiONCl}_{2}\right]} \\
{\left[\mathrm{NiO}_{2} \mathrm{Cl}_{2}\right]}\end{array}$ & $\begin{array}{c}3876 \\
8562 \\
15141 \\
25612\end{array}$ & $\begin{array}{c}{ }^{3} \mathrm{~T}_{1}(\mathrm{~F}) \rightarrow{ }^{3} \mathrm{~T}_{2}(\mathrm{~F}) \\
{ }^{3} \mathrm{~T}_{1}(\mathrm{~F}) \rightarrow{ }^{3} \mathrm{~A}_{2}(\mathrm{~F}) \\
{ }^{3} \mathrm{~T}_{1}(\mathrm{~F}) \rightarrow{ }^{3} \mathrm{~T}_{1}(\mathrm{P}) \\
\mathrm{CT}\end{array}$ \\
\hline $\mathrm{Ni}\left(\mathrm{NO}_{3}\right)_{2} \cdot \mathrm{L}$ & Light green & 4.28 & {$\left[\mathrm{NiO}_{3} \mathrm{~N}\right]$} & $\begin{array}{c}3977 \\
8658 \\
15280 \\
35714 \\
\end{array}$ & $\begin{array}{c}{ }^{3} \mathrm{~T}_{1}(\mathrm{~F}) \rightarrow{ }^{3} \mathrm{~T}_{2}(\mathrm{~F}) \\
{ }^{3} \mathrm{~T}_{1}(\mathrm{~F}) \rightarrow{ }^{3} \mathrm{~A}_{2}(\mathrm{~F}) \\
{ }^{3} \mathrm{~T}_{1}(\mathrm{~F}) \rightarrow{ }^{3} \mathrm{~T}_{1}(\mathrm{P}) \\
\mathrm{CT}\end{array}$ \\
\hline $\mathrm{NiSO}_{4} \cdot \mathrm{L}$ & Apple green & 4.12 & {$\left[\mathrm{NiO}_{3} \mathrm{~N}\right]$} & $\begin{array}{c}3912 \\
8420 \\
15396 \\
24454 \\
\end{array}$ & $\begin{array}{c}{ }^{3} \mathrm{~T}_{1}(\mathrm{~F}) \rightarrow{ }^{3} \mathrm{~T}_{2}(\mathrm{~F}) \\
{ }^{3} \mathrm{~T}_{1}(\mathrm{~F}) \rightarrow{ }^{3} \mathrm{~A}_{2}(\mathrm{~F}) \\
{ }^{3} \mathrm{~T}_{1}(\mathrm{~F}) \rightarrow{ }^{3} \mathrm{~T}_{1}(\mathrm{P}) \\
\mathrm{CT}\end{array}$ \\
\hline
\end{tabular}

TABLE-4

LIGAND FIELD PARAMETERS OF Co(II) AND Ni(II) COMPLEXES OF LIGAND

\begin{tabular}{|c|c|c|c|c|c|c|}
\hline Complex & $v_{2} / v_{1}$ & $\mathrm{~B}\left(\mathrm{~cm}^{-1}\right)$ & $\mathrm{Dq}\left(\mathrm{cm}^{-1}\right)$ & $\beta$ & $\beta \%$ & $\operatorname{LFSE}\left(\mathrm{kcal} \mathrm{cm}^{-1}\right)$ \\
\hline $\mathrm{CoCl}_{2} \cdot \mathrm{L} \cdot 2 \mathrm{H}_{2} \mathrm{O}$ & 2.171 & 887.4 & 799.2 & 0.914 & 8.61 & 27.40 \\
\hline $2 \mathrm{Co}\left(\mathrm{NO}_{3}\right)_{2} \cdot \mathrm{L}$ & 1.719 & 627.7 & 391.2 & 0.646 & 35.36 & 13.41 \\
\hline $2 \mathrm{CoSO}_{4} \cdot \mathrm{L} \cdot \mathrm{H}_{2} \mathrm{O}$ & 1.793 & 668.3 & 386.9 & 0.688 & 31.20 & 27.70 \\
\hline $2 \mathrm{NiCl}_{2} \cdot \mathrm{L} \cdot \mathrm{H}_{2} \mathrm{O}$ & 2.209 & 805.0 & 468.6 & 0.773 & 22.70 & 16.07 \\
\hline $\mathrm{Ni}\left(\mathrm{NO}_{3}\right)_{2} \cdot \mathrm{L}$ & 2.177 & 800.4 & 468.1 & 0.773 & 22.70 & 16.04 \\
\hline $\mathrm{NiSO}_{4} \cdot \mathrm{L}$ & 2.152 & 805.3 & 450.8 & 0.774 & 22.61 & 15.45 \\
\hline
\end{tabular}

Note: $B_{0}$ for Co(II): $971 \mathrm{~cm}^{-1}$, LFSE $=12 \mathrm{Dq}$ and $1 \mathrm{kcal} \mathrm{mol}^{-1}=350 \mathrm{~cm}^{-1} ; \mathrm{B}_{0}$ for $\mathrm{Ni}(\mathrm{II}): 1041 \mathrm{~cm}^{-1}, \mathrm{LFSE}=12 \mathrm{Dq}$ and $1 \mathrm{kcal} \mathrm{mol}^{-1}=350 \mathrm{~cm}^{-1}$ 
spin octahedral geometry around Co(II) $[31,32]$. The effective magnetic moment of $\mathrm{Co}$ (II) chloro complex is 5.16 B.M., which is expected for a high spin octahedral complex. The blue coloured $\mathrm{Co}$ (II) nitrato and sulphato complexes exhibited a absorption maxima at 3912-3869 $\mathrm{cm}^{-1}$ due to ${ }^{4} \mathrm{~A}_{2}(\mathrm{~F}) \rightarrow{ }^{4} \mathrm{~T}_{2}(\mathrm{~F})$ $\left(v_{1}\right)$; 6938-6726 $\mathrm{cm}^{-1}$ due to ${ }^{4} \mathrm{~A}_{2}(\mathrm{~F}) \rightarrow{ }^{4} \mathrm{~T}_{1}(\mathrm{~F})\left(\mathrm{v}_{2}\right)$; and $14693-$ $14426 \mathrm{~cm}^{-1}$ due to ${ }^{4} \mathrm{~A}_{2}(\mathrm{~F}) \rightarrow{ }^{4} \mathrm{~T}_{1}(\mathrm{P})\left(\mathrm{v}_{3}\right)$ transitions and at 26326 $-26168 \mathrm{~cm}^{-1}$ due to charge transfer transitions. The very low magnetic moment value of 1.09 B.M. measured for Co(II) nitrato complex may be attributed to anti-ferromagnetic interaction between the adjacent $\mathrm{Co}$ (II) ions in a binuclear pseudotetrahedral geometry. The magnetic moment of $\mathrm{Co}$ (II) sulphato complex measured at 4.21 B.M. is indicative of a tetrahedral geometry. The $v_{2} / v_{1}$ ratios for $\mathrm{Co}$ (II) nitrato and sulphato complexes measured at 1.719 and 1.793 , respectively are also supportive of tetrahedral stereochemistry around $\mathrm{Co}(\mathrm{II})$ ion.

The green coloured Ni(II) chloro, nitrato and sulphato complexes exhibited bands at $3977-3876 \mathrm{~cm}^{-1}$ due to ${ }^{3} \mathrm{~T}_{1}(\mathrm{~F})$ $\rightarrow{ }^{3} \mathrm{~T}_{2}(\mathrm{~F})\left(\mathrm{v}_{1}\right)$; at 8658-8420 $\mathrm{cm}^{-1}$ due to ${ }^{3} \mathrm{~T}_{1}(\mathrm{~F}) \rightarrow{ }^{3} \mathrm{~A}_{2}(\mathrm{~F})\left(\mathrm{v}_{2}\right)$; at $15641-15280 \mathrm{~cm}^{-1}$ due to ${ }^{3} \mathrm{~T}_{1}(\mathrm{~F}) \rightarrow{ }^{3} \mathrm{~T}_{1}(\mathrm{P})\left(\mathrm{v}_{3}\right)$ and at 35714$24454 \mathrm{~cm}^{-1}$ due to charge transfer transitions. The $v_{2} / v_{1}$ ratios observed for $\mathrm{Ni}$ (II) complexes are within the stipulated range of 2.00-2.24 for $\mathrm{T}_{\mathrm{d}}$ symmetry of $\mathrm{Ni}(\mathrm{II})$. The magnetic moment values of $\mathrm{Ni}$ (II) complexes are within the range of 4.12-4.28 B.M. indicating tetrahedral geometry around $\mathrm{Ni}(\mathrm{II})$ ion $[33,34]$.

Electrochemical studies: The redox behaviour of $\mathrm{CoCl}_{2}$. $\mathrm{L} \cdot 2 \mathrm{H}_{2} \mathrm{O}$ was studied as a representative case. The cyclic voltammograms of this complex were recorded at 50,250 and $500 \mathrm{mV} \mathrm{s}^{-1}$ scan rates $(v)$ and the redox properties are shown in Table-5. The cyclic voltammogram of complex scanned at $250 \mathrm{mV} \mathrm{s}^{-1}$ is represented in Fig. 2. The cyclic voltammograms feature the reduction of $\mathrm{Co}(\mathrm{II})$ to $\mathrm{Co}(\mathrm{I})$ at cathodic peak potentials
$1.5613-1.512 \mathrm{~V}[35,36]$. The separations between the anodic and cathodic peak potentials $\left(\Delta \mathrm{E}_{\mathrm{p}}\right)$ measured at $31-37 \mathrm{mV}$ indicate reversible one electron process. The voltammetric $\mathrm{E}_{1 / 2}$ values taken as the average of $\mathrm{E}_{\mathrm{pc}}$ and $\mathrm{E}_{\mathrm{pa}}$ are at 1.5576-1.5292 V showed that the present complex cannot undergo reduction easily at a more positive potential as the $\sigma$ donating ability of the chelating(NO) Mannich base would tend to stabilize $\mathrm{Co}$ (II) ion in the chelate. The peak current ratios $\left(\mathrm{i}_{\mathrm{pa}} / \mathrm{i}_{\mathrm{pc}}\right)$ are greater than unity at all scan rates showing that the electron transfer is not followed by a chemical reaction. The peak current increases with increase in $v^{1 / 2}$ to establish the electrode process to be diffusion controlled.

Thermal studies: Thermal data obtained for Mannich bases and its representative complexes are provided in Table- 6 .

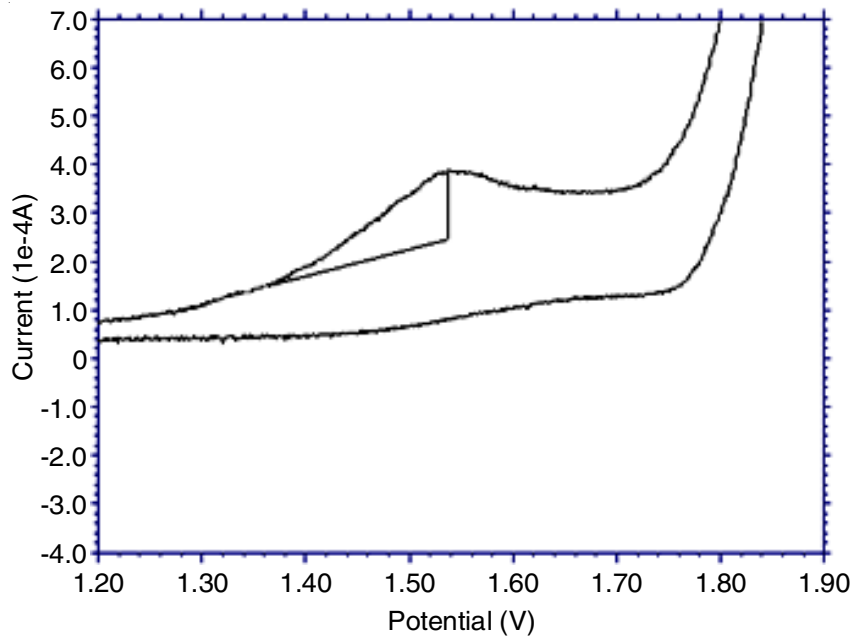

Fig. 2. Cyclic voltammogram of $\mathrm{CoCl}_{2} \cdot \mathrm{PMID} \cdot 2 \mathrm{H}_{2} \mathrm{O}$ at the scan rate of 250 $\mathrm{mV} \mathrm{s}^{-1}$

TABLE-5

ELECTROCHEMICAL DATA OF $\mathrm{COCl}_{2} \cdot \mathrm{L} \cdot 2 \mathrm{H}_{2} \mathrm{O}$ AT VARIOUS SCAN RATES

\begin{tabular}{cccccccc}
\hline Scan rate $\left(\mathrm{mVs}^{-1}\right)$ & $\mathrm{E}_{\mathrm{pa}}(\mathrm{V})$ & $\mathrm{E}_{\mathrm{pc}}(\mathrm{V})$ & $\Delta \mathrm{E}_{\mathrm{p}}(\mathrm{mV})$ & $\mathrm{E}_{1 / 2}(\mathrm{~V})$ & $\mathrm{i}_{\mathrm{pa}}(\mu \mathrm{A})$ & $\mathrm{i}_{\mathrm{pc}}(\mu \mathrm{A})$ & $\mathrm{i}_{\mathrm{pa}} / \mathrm{i}_{\mathrm{pc}}$ \\
\hline 50 & 1.5761 & 1.539 & 37 & 1.5576 & 112.7 & 27.96 & 4.031 \\
250 & 1.5464 & 1.512 & 34 & 1.5292 & 385.4 & 64.48 & 5.977 \\
500 & 1.5613 & 1.514 & 31 & 1.5376 & 627.6 & 69.84 & 8.986 \\
\hline
\end{tabular}

TABLE-6

TG/DTG/DTA DATA FOR LIGAND AND ITS METAL COMPLEXES

\begin{tabular}{|c|c|c|c|c|c|c|c|}
\hline \multirow[t]{2}{*}{ Compound } & \multirow{2}{*}{$\begin{array}{l}\text { Stable } \\
\text { upto } \\
\left({ }^{\circ} \mathrm{C}\right)\end{array}$} & \multirow[t]{2}{*}{ Stage } & \multicolumn{2}{|c|}{$\begin{array}{l}\text { Decomposition } \\
\text { temperature }\left({ }^{\circ} \mathrm{C}\right)\end{array}$} & \multirow{2}{*}{$\begin{array}{l}\text { Nature of transformation/ } \\
\text { Intermediate formed/ } \\
\% \text { Mass found (calc.) }\end{array}$} & \multirow{2}{*}{$\begin{array}{l}\text { Nature of DTA } \\
\text { peak and temp. } \\
\left({ }^{\circ} \mathrm{C}\right)\end{array}$} & \multirow{2}{*}{$\begin{array}{l}\text { DTG peak } \\
\text { temp. }\left({ }^{\circ} \mathrm{C}\right)\end{array}$} \\
\hline & & & Initial & Final & & & \\
\hline \multirow{3}{*}{$\mathrm{L}\left(\mathrm{C}_{13} \mathrm{H}_{14} \mathrm{~N}_{2} \mathrm{O}_{2}\right)$} & \multirow{3}{*}{193.2} & & & & Melting point & 122.07 Endo & - \\
\hline & & I & 193 & 300 & $\begin{array}{l}\text { Decomposition of land formation of a polymer of } \\
\text { formaldehyde }(\mathrm{R})\end{array}$ & - & 241.64 \\
\hline & & II & 450 & 500 & $\begin{array}{l}\text { Presence of high polymer of formaldehyde as a } \\
\text { stable final residue. }\end{array}$ & 490.0 Exo & 489.5 \\
\hline \multirow{3}{*}{$2 \mathrm{CoSO}_{4} \cdot \mathrm{L} \cdot \mathrm{H}_{2} \mathrm{O}$} & \multirow{3}{*}{80.0} & $\mathrm{I}$ & 80 & 90 & Elimination of lattice water & 90.0 Endo & 79.06 \\
\hline & & II & 105 & 140 & $\begin{array}{l}\text { Elimination of coordinated water to give } \\
\text { anhydrous complex }\end{array}$ & 112.5 Endo & 109.14 \\
\hline & & III & 210 & 320 & $\begin{array}{l}\text { Elimination of } \mathrm{L} \text { to give } \mathrm{CoSO}_{4} \text { as final residue } \\
\text { (G) } 57.2(56.38)\end{array}$ & 299.7 Endo & 295.3 \\
\hline \multirow{3}{*}{$2 \mathrm{NiCl}_{2} \cdot \mathrm{L} \cdot \mathrm{H}_{2} \mathrm{O}$} & \multirow{3}{*}{71.0} & I & 71 & 105 & $\begin{array}{l}\text { Elimination of coordinated water to form } \\
\text { anhydrous complex }(G) 87.0(89.8)\end{array}$ & 75.0 & 71.0 \\
\hline & & II & 190 & 225 & $\begin{array}{l}\text { Elimination of } \mathrm{L} \text { to form } \mathrm{NiCl}_{2} \text { as intermediate } \\
\text { (G) } 54.3(52.85)\end{array}$ & 222.0 Endo & 218.4 \\
\hline & & III & 500 & 800 & Conversion of $\mathrm{NiCl}_{2}$ into $\mathrm{NiO}(\mathrm{G}) .29 .2(30.38)$ & 556.0 Exo & 579.0 \\
\hline
\end{tabular}

Note: $(\mathrm{R})=$ rapid, $(\mathrm{G})=$ gradual and $(\mathrm{S})=$ slow decomposition; Exo = exothermic, Endo = endothermic 


\begin{tabular}{|c|c|c|c|c|c|c|c|c|c|c|c|c|c|c|c|c|}
\hline \multicolumn{17}{|c|}{$\begin{array}{c}\text { TABLE-7 } \\
\text { ANTIBACTERIAL AND ANTIFUNGAL ACTIVITIES OF MANNICH BASE LIGAND (L) AND ITS METAL COMPLEXES }\end{array}$} \\
\hline \multirow{5}{*}{ Compound } & \multicolumn{16}{|c|}{ Zone of inhibition $(\mathrm{mm})$} \\
\hline & \multicolumn{8}{|c|}{ Antibacterial activity } & \multicolumn{8}{|c|}{ Antifungal activity } \\
\hline & \multicolumn{4}{|c|}{ E. coli } & \multicolumn{4}{|c|}{ S. aureus } & \multicolumn{4}{|c|}{ A. niger } & \multicolumn{4}{|c|}{ C. albicans } \\
\hline & \multicolumn{4}{|c|}{ Conc. $(\mu \mathrm{g} / \mathrm{mL})$} & \multicolumn{4}{|c|}{ Conc. $(\mu \mathrm{g} / \mathrm{mL})$} & \multicolumn{4}{|c|}{ Conc. $(\mu \mathrm{g} / \mathrm{mL})$} & \multicolumn{4}{|c|}{ Conc. $(\mu \mathrm{g} / \mathrm{mL})$} \\
\hline & 25 & 50 & 75 & 100 & 25 & 50 & 75 & 100 & 25 & 50 & 75 & 100 & 25 & 50 & 75 & 100 \\
\hline $\mathrm{L}\left(\mathrm{C}_{13} \mathrm{H}_{14} \mathrm{~N}_{2} \mathrm{O}_{2}\right)$ & 11 & 12 & 13 & 14 & 9 & 11 & 13 & 14 & 7 & 9 & 12 & 13 & 8 & 9 & 12 & 13 \\
\hline $\mathrm{CoCl}_{2} \cdot \mathrm{L} \cdot 2 \mathrm{H}_{2} \mathrm{O}$ & 11 & 14 & 17 & 20 & 12 & 15 & 18 & 21 & 12 & 15 & 18 & 21 & 11 & 14 & 17 & 20 \\
\hline $2 \mathrm{CoSO}_{4} \cdot \mathrm{L} \cdot \mathrm{H}_{2} \mathrm{O}$ & 11 & 13 & 15 & 19 & 11 & 14 & 17 & 19 & 11 & 14 & 17 & 19 & 11 & 13 & 15 & 19 \\
\hline $2 \mathrm{NiCl}_{2} \cdot \mathrm{L} \cdot \mathrm{H}_{2} \mathrm{O}$ & 10 & 12 & 14 & 18 & 10 & 12 & 15 & 18 & 10 & 12 & 15 & 18 & 10 & 12 & 14 & 18 \\
\hline $\mathrm{NiSO}_{4} \cdot \mathrm{L}$ & 11 & 14 & 17 & 20 & 12 & 15 & 18 & 21 & 12 & 15 & 18 & 21 & 11 & 14 & 17 & 20 \\
\hline Kanamycin & 8 & - & - & - & - & - & - & - & - & - & - & - & - & - & - & - \\
\hline Tetracyclin & - & - & - & - & 9 & - & - & - & - & - & - & - & - & - & - & - \\
\hline Amphotericin & - & - & - & - & - & - & - & - & 10 & - & - & - & - & - & - & - \\
\hline Nystatin & - & - & - & - & - & - & - & - & - & - & - & - & 9 & - & - & - \\
\hline
\end{tabular}

The TG/DTA thermogram obtained for the ligand shows a two stage decomposition. An endotherm found at $122.07^{\circ} \mathrm{C}$ indicates the melting of Mannich base, but compound is stable upto $193^{\circ} \mathrm{C}$. The first stage of decomposition and weight loss occurred in the temperature range $193-300{ }^{\circ} \mathrm{C}$ as indicate by DTG peak at $241.64{ }^{\circ} \mathrm{C}$. The second stage of slow decomposition occurs in the range $450-500{ }^{\circ} \mathrm{C}$ as shown by exotherm at $490^{\circ} \mathrm{C}$ and DTG peak at $489.5^{\circ} \mathrm{C}$. The final residue existing above $500{ }^{\circ} \mathrm{C}$ may be a polymer of formaldehyde (one of the decomposition products of ligand).

The aqua complex $2 \mathrm{CoSO}_{4} \cdot \mathrm{L} \cdot \mathrm{H}_{2} \mathrm{O}$ eliminates coordinated water in the temperature range $105-140^{\circ} \mathrm{C}$ as evidenced by the endotherm at $112.54^{\circ} \mathrm{C}$ and a DTG peak centered at $109.14^{\circ} \mathrm{C}$. The anhydrous complex undergoes gradual decomposition in the range $210-320^{\circ} \mathrm{C}$ with the loss of organic ligand to give a residue of $\mathrm{CoSO}_{4}$, as indicated by the endotherm at $299.7^{\circ} \mathrm{C}$ and also by the DTG peak at $295.3^{\circ} \mathrm{C}$.

The $\mathrm{Ni}$ (II) aqua complex rapidly loses water in the range $75-105^{\circ} \mathrm{C}$ as indicated by the endotherm at $\sim 75^{\circ} \mathrm{C}$ to form the anhydrous complex. This in the range $190-225^{\circ} \mathrm{C}$ eliminates the organic ligand to form $\mathrm{NiCl}_{2}$ as intermediate, as evidenced by the endothermic DTA peak at $222{ }^{\circ} \mathrm{C}$ and the DTG peak at $218.4{ }^{\circ} \mathrm{C}, \mathrm{NiCl}_{2}$ intermediate undergoes gradual conversion into $\mathrm{NiO}$ above $500{ }^{\circ} \mathrm{C}$. The exotherm found at $556^{\circ} \mathrm{C}$ and DTG peak at $579^{\circ} \mathrm{C}$ are supportive of formation of $\mathrm{NiO}$ as final residue.

Antimicrobial activity: Imide molecules possess a -CO$\mathrm{N}(\mathrm{R})-\mathrm{CO}$ - structural feature and a ring structure making them liphophilic and neutral and hence they can cross the biological membranes easily. Thus, the imide derivatives are known to exhibit several biological activities. When imides are transformed into Mannich bases they may have enhanced activities. In view of this, in vitro antibacterial and antifungal activities of ligand and its $\mathrm{Co}$ (II) and $\mathrm{Ni}$ (II) complexes have been evaluated. All the metal complexes as well as Mannich base ligand exhibited a significant antimicrobial activity (Table-7). The metal complexes are more active against bacteria and fungi than the free ligand. This reason might be ascribed due to the chelation, which reduces the polarity of metal atom and enhances the liphophilic nature of metal complex favouring the diffusion of the chelate molecule through the lipid layer of microbial cell membrane. Thus, the higher activity of metal(II) complexes may be ascribed to increase in liphophilic nature of the complexes arising from chelation [37]. The hydrogen bonding and other interactions between the donor groups present in the enzymes of microbes and imido carbonyl groups present in the chelate molecules may interfere in the process of protein synthesis and cell wall synthesis leading to the lysis of cells. Also the activity increases when concentrations of test compounds are increased. The activities of metal complexes at higher concentrations are comparable to those of the standard drugs. The Co(II) complexes have enhanced antimicrobial activities when compared with $\mathrm{Ni}(\mathrm{II})$ complexes (Table-7).

\section{CONFLICT OF INTEREST}

The authors declare that there is no conflict of interests regarding the publication of this article.

\section{REFERENCES}

1. V. Cechinel Filho, F. Campos, R. Corrêa, R.A. Yunes and R.J. Nunes, Quim. Nova, 26, 230 (2003);

https://doi.org/10.1590/S0100-40422003000200016.

2. F. Hassazadeh, M. Rabbani, G.A. Khodarahmi, G.H. Hakimelalahi, A. Fasihi and M. Mohajeri, Res. Pharm. Sci., 2, 35 (2007).

3. S.M. Sami, R.T. Dorr, D.S. Alberts, A.M. Sólyom and W.A. Remers, J. Med. Chem., 43, 3067 (2000); https://doi.org/10.1021/jm9905817.

4. J.A. Yunes, A.A. Cardoso, R.A. Yunes, R. Corrêa, F. de Campos-Buzzi and V.C. Filho, Z. Naturforsch. C, 63, 675 (2008); https://doi.org/10.1515/znc-2008-9-1011.

5. S.P. Mahapatra, P. Ghode, D.K. Jain, S.C. Chaturvedi, B.C. Maiti and T.K. Maity, J. Pharm. Sci. Res., 2, 567 (2010).

6. X. Collin, J.-M. Robert, G. Wielgosz, G. Le Baut, C. Bobin-Dubigeon, N. Grimaud and J.-Y. Petit, Eur. J. Med. Chem., 36, 639 (2001); https://doi.org/10.1016/S0223-5234(01)01254-5.

7. S. Kawaguchi and O. Ikeda, Jpn. Pat. Appl. JP2001328911 (2001).

8. K. Ebihara, T. Oora, M. Nakaya, S. Shiraishi and N. Yasui, Jpn. Pat. Appl. JP08245585 (1996).

9. C.S. Chidan Kumar, W.-S. Loh, S. Chandraju, Y.-F. Win, W.K. Tan C.K. Quah and H.-K. Fun, PLoS ONE, 10, e0119440 (2015); https://doi.org/10.1371/journal.pone.0119440.

10. A.J. Abdulghani and N.M. Abbas, Bioinorg. Chem. Appl., 2011, Article ID 706262 (2011); https://doi.org/10.1155/2011/706262.

11. A.A. Raj, R. Raghunathan, M.R. Sridevi Kumari and N. Raman, Bioorg. Med. Chem., 11, 407 (2003); https://doi.org/10.1016/S0968-0896(02)00439-X. 
12. I. Stylianakis, A. Kolocouris, N. Kolocouris, G. Fytas, G.B. Foscolos, E. Padalko, J. Neyts and E. De Clercq, Bioorg. Med. Chem. Lett., 13, 1699 (2003); https://doi.org/10.1016/S0960-894X(03)00231-2.

13. J. Obniska, S. Jurczyk, A. Zejc, K. Kaminiski, E. Tatarcynska and K. Stachowicz, Pharmacol. Rep., 57, 170 (2005).

14. J. Obniska and A. Zagorska, Farmaco, 58, 1227 (2003); https://doi.org/10.1016/S0014-827X(03)00187-3.

15. N. Kolocouris, G.B. Foscolos, A. Kolocouris, P. Marakos, N. Pouli, G. Fytas, S. Ikeda and E. De Clercq, J. Med. Chem., 37, 2896 (1994); https://doi.org/10.1021/jm00044a010.

16. M.R. Abdullahi and S. Rajeswari, Proceedings, Article No. 1106856 (2016).

17. D. Tamilvendan, S. Rajeswari, S. Ilavenil and G.V Prabhu, Orbital Elec. J. Chem., 2, 10 (2010).

18. M. Ramesh, Ph.D. Thesis, Synthesis, Characterization and Antimicrobial Studies on Metal Complexes of New Mannich Bases Derived from Phthalimide and Succinimide, Bharathidasan University, Tiruchirappalli, India (2011).

19. J. Bassett, R.C. Denney, G.H. Jeffery and J. Hendham, Vogel's Text Book of Quantiative Analysis, ELBS: Longman, edn 4 (1986).

20. A. Earnshaw, Introduction to Magneto-Chemistry, Academic Press: New York (1968).

21. A.J. Bard and L.R. Isata, Electrochemical Methods: Fundamentals and Applications, John Wiley \& Sons: USA (1980).

22. R.M. Silverstein and F.X. Webster, Spectrometric Identification of Organic Compounds, John Wiley \& Sons Inc.: New York, edn 6 (1997).

23. L.J. Bellamy, The Infrared Spectra of Complex Molecules, Methuer: London, edn 2 (1958).

24. P. Sakthivel, P.S. Joseph, A. Sebastiyan, M.Y. Suvaikin and M. Ramesh, Acta Crystallogr. Sect. E Struct. Rep. Online, 63, o4388 (2007); https://doi.org/10.1107/S1600536807050519.
25. G. Shankar, P.S. Joseph, M. Yosuva Suvakin and A. Sebastiyan, Physica $B, \mathbf{4 0 5}, 4231$ (2010); https://doi.org/10.1016/j.physb.2010.07.016.

26. W.J. Geary, Coord. Chem. Rev., 7, 81 (1971); https://doi.org/10.1016/S0010-8545(00)80009-0.

27. H. Adams, N. Bailey, T.N. Briggs, J.A. McCleverty, H.M. Colquhoun and D.J. Williams, J. Chem. Soc., Dalton Trans., 813 (1986); https://doi.org/10.1039/DT9860000813.

28. I.J.S. Fairlamb, A.R. Kapdi, A.F. Lee, G. Sanchez, G. Lopez, J.L. Serrano, L. Garcia, J. Perez and E. Perez, J. Chem. Soc., Dalton Trans., 3970 (2004); https://doi.org/10.1039/B413886D.

29. J.R. Ferraro, Low Frequency Vibrations of Inorganic and Coordination Compounds, Plenum Press: New York (1971).

30. K. Nakamato, Infrared and Raman Spectra of Inorganic and Coordination Compounds, Wiley Interscience: New York, edn 3, p. 156 (1978).

31. D.M.L. Goodgame, M. Goodgame and F.A. Cotton, J. Am. Chem. Soc., 83, 4161 (1961); https://doi.org/10.1021/ja01481a014.

32. A.B.P. Lever, Inorganic Electronic Spectroscopy, Elsevier: Amsterdam (1968).

33. B.N. Figgis and J. Lewis, Progress in Inorganic Chemistry, Interscience: New York, vol. 6 (1964).

34. L. Sacconi, J. Am. Chem. Soc., 76, 3400 (1954); https://doi.org/10.1021/ja01642a012.

35. H. Arslan, N.O. Pozan and N. Tarkan, Thermochim. Acta, 383, 69 (2002); https://doi.org/10.1016/S0040-6031(01)00657-8.

36. A.D. Kulkarni, S.A. Patil and P.S. Badami, Int. J. Electrochem. Sci., 4, 717 (2009).

37. R.S. Joseyphus and M.S. Nair, Arab. J. Chem., 3, 195 (2010); https://doi.org/10.1016/j.arabjc.2010.05.001. 